\title{
DEVELOPMENT AND INVESTIGATION OF THERMAL INSULATION FROM HEMP-POLYLACTIDE FIBRES
}

\author{
Rūta STAPULIONIENÉa ${ }^{a}$, Ramūnas TUPČIAUSKAS ${ }^{\mathrm{b}}$, Saulius VAITKUS ${ }^{\mathrm{a}}$, Sigitas VĖJELIS ${ }^{\mathrm{a}}$ \\ ${ }^{a}$ Scientific Institute of Thermal Insulation, Vilnius Gediminas Technical University, \\ Linkmenu g. 28, LT-08217 Vilnius, Lithuania \\ ${ }^{b}$ Latvian State Institute of Wood Chemistry, Dzerbenes str. 27, LV-1006, Riga, Latvia
}

Received 03 February 2016; accepted 21 February 2016

\begin{abstract}
In the last two decades intensive grow of industry of building materials from renewable resources is observed. Such situation is related to some aspects: global warming, environmental pollution, impact on human health, environmental impact of materials at their end-of-life.

In current study development of thermal insulation materials from hemp and polylactide fibres are analysed. While main parameter for thermal insulation materials is thermal conductivity, rational density of composite $40 \mathrm{~kg} / \mathrm{m}^{3}$ was chosen. For experiments 11 compositions were prepared. One composition was prepared just with hemp and polylactide fibres, five compositions with different amount of hydrophobic agent and 5 compositions with different amount of fire retardant. Experimentally thermal conductivity, sound absorption coefficient, short-term water absorption, fire resistance, water vapour transfer properties and compressive strength were determined. Rational amount of hydrophobic agent and fire retardants was chosen.
\end{abstract}

Keywords: thermal insulation materials, hemp fibers, polylactide, thermal conductivity, sound absorption coefficient, short-term water absorption, fire resistance.

\section{Introduction}

The use of thermal insulation materials dates back to 3000 years ago, when straw was reinforced with clay and used to build walls (Spiridon 2014). Materials based on natural resources, like reed grass, straw, hay, linen, hemp or lichens have been used for thermal insulation purposes for ages. These materials were often located on the building envelope; certain kinds of green facades and roofs can be seen with lichens. However, as the society developed requirements for good make and high quality of buildings increased, they were replaced by new synthetic materials, mostly polymeric, like polystyrene, polyvinylchloride, polyethylene and inorganic synthetic materials like mineral or glass wool (Korjenic et al. 2015; Chybik 2009).

In current time the European market of insulating materials is characterized by the domination of two types of products, namely inorganic fibrous materials, glass wool and stone wool, which account for $60 \%$ of the market, and organic foamy materials, expanded and extruded polystyrene and to a lesser extent polyurethane, which account for some $27 \%$ of the market (Papadopoulos 2005). According to Spain researchers (Palumbo et al. 2015), the renewable alternative, i.e. natural insulation materials represent less than $2 \%$ of the market.

The use of natural fibers is an area of increasing interest, and opportunities are being developed in new markets. Historically natural fibers have been used extensively by the textile industries. Nowadays, accumulating research has highlighted their attractive properties and benefits: efficient thermal resistivity, good structural strength, moisture buffering capacity and the uptake of certain gasses (Mansour et al. 2014).

Corresponding author:

R. Stapulionienè E-mail: ruta.stapulioniene@vgtu.lt 
The use of natural fibers presents many advantages, such as (Palumbo et al. 2015):

- renewable annually, in contrast to wood, which has longer generation cycles;

- compostable, which may contribute to the reduction of waste going to landfills, and to the development of an industry based on closed production cycles where the concept of waste disappears;

- easily accessible and do not compete in fertile land use with food production, as is the case of industrial fibers;

- their valorization may contribute to diversify the market for farmers;

- their internal structure makes them naturally low thermal conductors, which may mean that they do not need to be highly transformed to achieve the thermal requirements for insulation materials;

- their hygroscopic behavior may contribute to maintaining comfort in buildings.

Hemp fibers have the potential to be used as glass fibers replacement in certain composite applications (Hepworth et al. 2000). The hemp stem can reach a height of more than four meters when the plant has good growth conditions (Thomsen et al. 2005). Researches (Jankauskienè, Gruzdevienè 2015) have stated that hemp plants can produce more than $40 \mathrm{t} / \mathrm{ha}$ biomass. The highest moisture content of absolutely dry mass was $70.6 \%$ and the highest content of absolutely dry mass was $14.3 \mathrm{t} / \mathrm{ha}$.

In work (Lukošiūte 2014) it is stated that during processing $1 \mathrm{t}$ of hemp stem $250 \mathrm{~kg}$ of fibers can be obtained. From all obtained content of fibers in industry just $5-6 \%$ is used for thermal insulation.

A wide range of insulation materials made from natural fibers is already being produced for different application areas (Müssig 2010; Papadopoulos 2005): insulating felts, panel absorbers, blowing insulation, pouring insulation, impact sound insulation materials and ceiling panels, mats and boards.

There are several ways to produce hemp fibers insulation. For production of felts the fibers are oriented by a roller carding machine or an aerodynamic laying machine and processed into a planar-arranged entity (Müssig 2010). The fibers are then hardened to a needle felt by means of a needle process using fibers tangles and adjustable needle density.
For mats and boards production often thermalbonding technology is used (Freivalde et al. 2014; Mansour et al. 2014; Corscadden et al. 2014). Mechanically treated fibers are mixed with an appropriate proportion of a binder, usually a low melt synthetic fiber such as polyester, polypropylene, polylactide, polyolefin or a wet adhesive (Mansour et al. 2014; Spiridon 2014; Sain et al. 2004; Huber, Müssig 2008). Treatments including flame retardants and pesticides may be applied at the mixing stage to ensure proper distribution throughout the thickness of the final product, or may be sprayed on the surface of the final product at later stages. In carding process mixed fibers are combed into the same direction, to create a batt. Thermal bonding is processed in belt oven where prepared batt is exposed to hot air flow. Temperature of air flow depends on the matrix material.

Aim of this paper is to develop thermal insulation material from hemp fibres and polylactide fibres having low thermal conductivity, high sound absorption coefficient, low water absorption and flammability, good water vapour transfer properties.

\section{Methodology}

\subsection{Materials and their preparation}

Hemp fibres received from fibre hemp (variety USO 31) grown in the Northern Lithuania were used. Long hemp fibres were prepared by decorticator in Lithuanian Research Centre for Agriculture and Forestry, separating fibres from shives. Long fibres were chopped up to $20-30 \mathrm{~mm}$ in length and mixed with polylactide (PLA) fibres. PLA was used as matrix material. Polylactide fibres were supplied by MAXModel s.a.s, France. Main characteristics of PLA fibres are such: 4.4 dtex, $51 \mathrm{~mm}$ in length and $130{ }^{\circ} \mathrm{C}$ melt temperature. Polylactide is low flammability artificial fibre, produced from bio-based products (corn) by biotechnology. It is alternative to the synthetic non-biodegradable fibre. The hemp-polylactide webs in ratios 89:11 and 85:15 were produced by carding technique in JSC Neaustima, Lithuania. During carding process mixed fibres were combed into the same direction, to create composite webs. The resulting web of aligned fibres was then cross laid into several layers that overlapped. The degree of overlap depended on the desired density of the product. Prepared webs were conveyed through an oven to allow polylactide fibres to melt. The thickness and density of composite was controlled by two drums, through which material was conveyed. After 


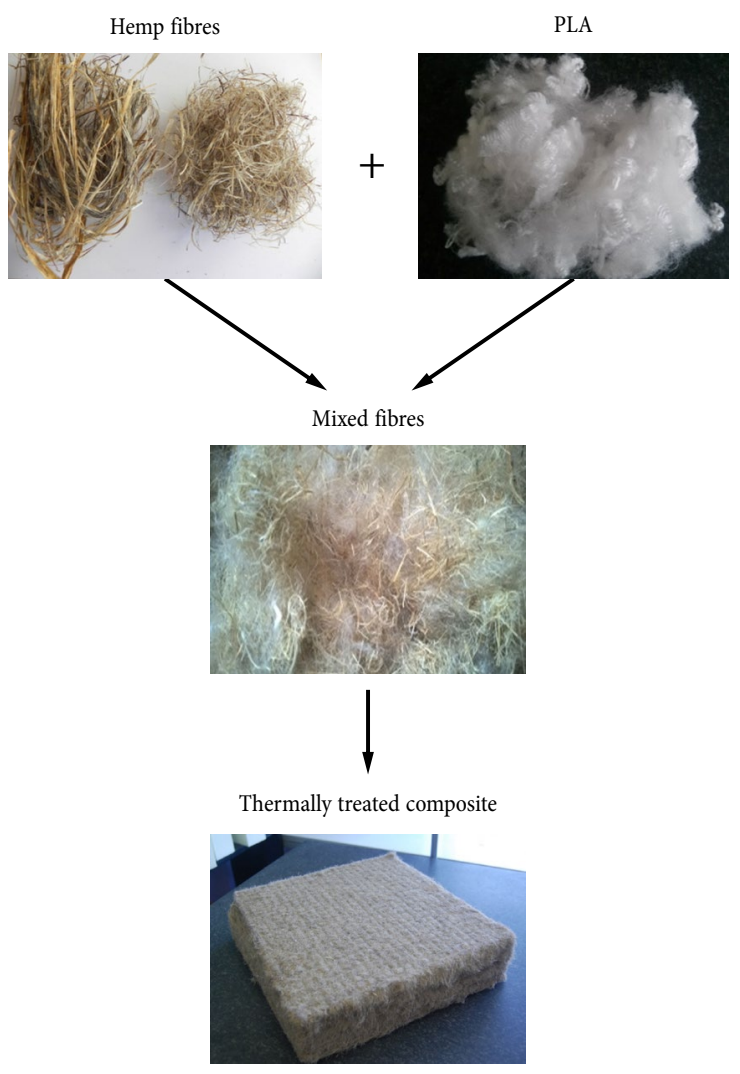

Fig. 1. The principal scheme of composite preparation

compression between drums material was conveyed out from oven and natural cooled in ambient air temperature to provide dimension stability to the product. Thermally treated composite was cut to the required length and width. The principal scheme of composite production is presented in Figure 1.

\subsection{Test methods}

Thermal conductivity tests were performed using heat flow meter apparatus FOX 304 (LaserComp, USA). Measurement range of the apparatus is from $0.5 \mathrm{~W} /$ $(\mathrm{m} \times \mathrm{K})$ to $0.004 \mathrm{~W} /(\mathrm{m} \times \mathrm{K})$ with centrally located heat flux transducers having dimensions of $(100 \times 100) \mathrm{mm}$. Thermal insulating properties of material was measured in accordance with LST EN 12667 and LST EN ISO 8301.

The sound absorption coefficient was established in accordance with EN ISO 10534-1 using the impedance tube method. With this method it is possible to readily obtain measurements of normal incidence parameters using small samples. The Kundt's tube had an internal diameter of $85 \mathrm{~mm}$ and length of $1000 \mathrm{~mm}$. Before use test equipment was checked by a series of tests. The working frequency range was from 150 to $2000 \mathrm{~Hz}$. Thicknesses of specimens was $50 \mathrm{~mm}$.
Compressive strength was determined according to LST EN 826. Test specimens of dimensions $(100 \times 100 \times 50) \mathrm{mm}$ were used. The test were conducted by using a computerised testing machine H10KS (Hounsfield, England). The rate of loading was (0.1 $\mathrm{N} \pm 25 \%) \mathrm{mm} / \mathrm{min}$. Before tests specimens for 24 hours at the ambient temperature of $(23 \pm 2){ }^{\circ} \mathrm{C}$ and relative humidity of $(50 \pm 5) \%$ were stored.

Short-term water absorption by partial immersion was conducted according to LST EN 1609 method A. The dimensions of the test specimens were $(100 \times 100 \times 50) \mathrm{mm}$. Before test all specimens were conditioned for 24 hours at $(23 \pm 2){ }^{\circ} \mathrm{C}$ temperature and relative humidity of $(50 \pm 5) \%$. Each test specimen was placed in the water tank in such position that it was partially immersed in water with its bottom face $(10 \pm 2) \mathrm{mm}$ below the water level. To keep specimens partially immersed sufficient load was applied. After testing short-term water absorption by partial immersion, $W_{p}$ was calculated in kilograms per square metre, using the following formulae:

$$
W_{p}=\frac{m_{24}-m_{0}}{A_{p}},
$$

where $m_{0}$ is the initial mass of the test specimen, in kilograms, $m_{24}$ is the mass of the test specimen after partial immersion for 24 hours, in kilograms; $A_{p}$ is the bottom surface area of the test specimen, in square meters.

Water vapour transmission properties were determined according to LST EN 12086 test conditions C. Five test specimens were tested. Dimensions of test specimens were $(100 \times 100 \times 50) \mathrm{mm}$. Each test specimen was sealed to the open side of a test dish containing an aqueous saturated salt solution. The assembly was then placed in a test atmosphere whose temperature and humidity were controlled. Because of the difference between the partial water vapour pressures in the test assembly and in test atmosphere water vapour flows through the test specimen. Periodic weighing of the assembly were conducted to determine the rate of water vapour transmission when the steady state is reached.

Reaction to fire tests were performed accordance with LST EN ISO 11925-2. The ignitability method is based by direct small flame impingement under zero impressed irradiance using vertically oriented test specimens. The flame application time was $15 \mathrm{~s}$. During the experiment was fixed such information: 
- whether ignition occurs;

- how flame spread above the flame application point;

- presence of flaming drop particles which cause ignition of the filter paper.

For experiments two types of fire retardants were chosen - Flovan CGN and Apyrol BKW. Apyrol BKW - commercially available phosphorus and Sulphur compound (CHT-Bezema) and Flovan CGN nitrogen containing phosphonic acid salt (Huntsman). Selecting flame retardants two main conditions were taken into account - whether there are suitable for coating materials by immersion and by spraying methods as well as their minimal impact on the environment. For test six specimens were prepared with different concentration of chosen fire retardants.

\section{Test results and discussions}

\subsection{Thermal conductivity}

The essential requirements for buildings are energy savings and heat retention. Therefore, in order to save and preserve heat inside the buildings efficient thermal insulating materials must be used.

Hemp fibre composites with densities $\sim 40 \mathrm{~kg} / \mathrm{m}^{3}$ and $\sim 90 \mathrm{~kg} / \mathrm{m}^{3}$ were prepared for thermal conductivity analysis. Test results of thermal conductivity measurements are presented in Figure 2.

The experimental data show that increase of density from $40 \mathrm{~kg} / \mathrm{m}^{3}$ to $90 \mathrm{~kg} / \mathrm{m}^{3}$ of hemp fibre composite with $11 \%$ PLA decrease thermal conductivity about $3.8 \%$. For the same densities of hemp fibre composites with $15 \%$ PLA decrease of $4.4 \%$ is observed. Increasing the density of material, air gaps between the fibres reduce. The smaller air gaps between fibres lead to a slower heat transmission by gas conduction. Compar-

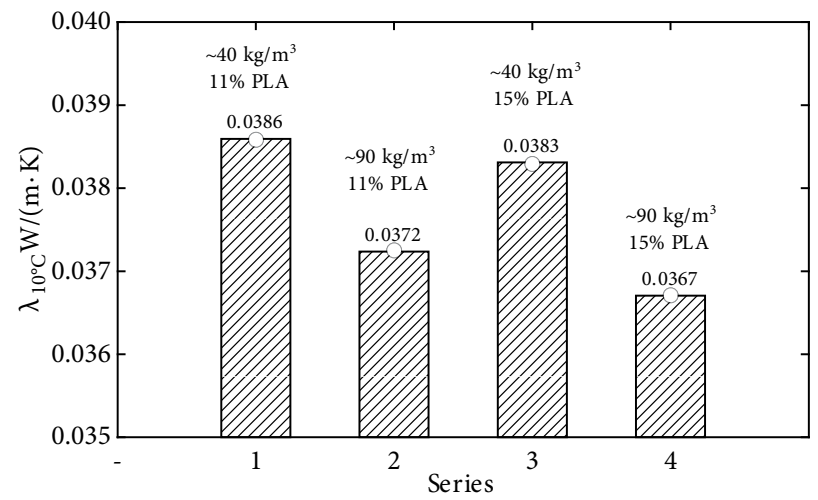

Fig. 2. Thermal conductivity coefficient of hemp fibre composites ing hemp fibre composites with $11 \%$ and $15 \%$ PLA shows that thermal conductivity values of specimens with density of $40 \mathrm{~kg} / \mathrm{m}^{3}$ differs about $0.78 \%$ and in case with density of $90 \mathrm{~kg} / \mathrm{m}^{3}$ - about $1.36 \%$.

Other authors (Korjenic et al.) 2016 have investigated composites from natural fibres (jute, flax, hemp) with densities from $26.1 \mathrm{~kg} / \mathrm{m}^{3}$ to $95.5 \mathrm{~kg} / \mathrm{m}^{3}$. They have determined that thermal conductivity values changes from $0.0399 \mathrm{~W} /(\mathrm{m} \times \mathrm{K})$ to $0.0500 \mathrm{~W} /(\mathrm{m} \times \mathrm{K})$. In such way we can state that our composites have lower thermal conductivity values and this difference may be due to raw materials preparation and formation peculiarities.

\subsection{Compressive strength characteristics}

In most cases for thermal insulating materials (Gnip et al. 2010) determination of limit strength is complicated. For this reason other indicator - compressive stress at $10 \%$ deformation - is used. In Figure 3 experimental analysis of compression data of hemp fibre composite with binding materials content of $11 \%$ and $15 \%$ PLA is presented. Comparison of compressive strength between samples with $11 \%$ and $15 \%$ PLA and with density of $40 \mathrm{~kg} / \mathrm{m}^{3}$ shows that difference amounted to $108 \%$ and in case with density of $96 \mathrm{~kg} /$ $\mathrm{m}^{3}$ - only $21.4 \%$.

For specimens used for compressive strength testing elasticity modulus between samples with $11 \%$ and $15 \%$ PLA and with density of $40 \mathrm{~kg} / \mathrm{m}^{3}$ shows difference $91.5 \%$ and in case with density of $96 \mathrm{~kg} / \mathrm{m}^{3}$ about $143 \%$.

For specimens used for compressive strength testing elasticity modulus between samples with $11 \%$ and $15 \%$ PLA and with density of $40 \mathrm{~kg} / \mathrm{m}^{3}$ shows difference $91.5 \%$ and in case with density of $96 \mathrm{~kg} / \mathrm{m}^{3}$ about $143 \%$.

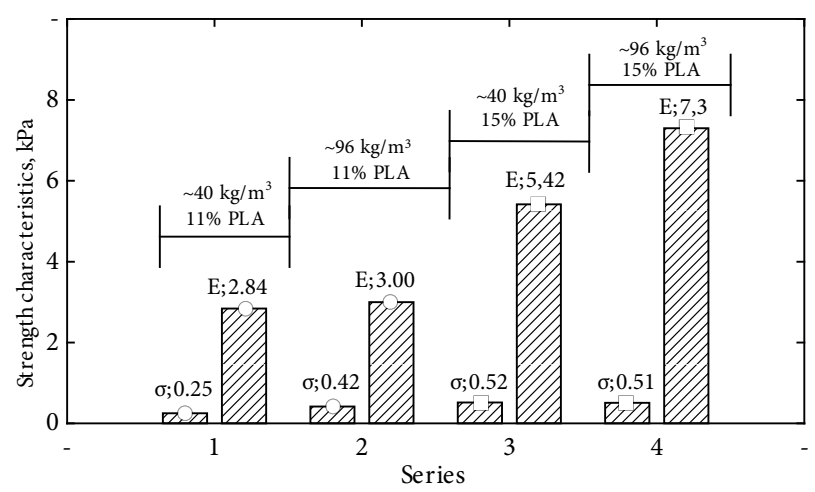

Fig. 3. Compressive strength characteristics of hemp fibre composites 
Test result analysis show that it is rational to produce composites with density of $40 \mathrm{~kg} / \mathrm{m}^{3}$ and amount of PLA 15\%. Increasing amount of polylactide fibres from $11 \%$ and $15 \%$ in composite with density of $40 \mathrm{~kg} /$ $\mathrm{m}^{3}$ increases strength about 2 times.

In most works compression characteristics are not analysed. For classic wool insulation (LST EN 13162, LST EN 13171) declaration of compressive strength is not required if this indicator is lower than $10 \mathrm{kPa}$. It mean that such products cannot be installed in building enclosures for bearing application. For higher values other binding materials or production technologies must be used.

\subsection{Sound absorption coefficient}

For determination of sound absorption coefficient 4 series of specimens were used. Test results are presented in Fig. 4. Test results show sudden growth of sound absorption coefficient which lasts until $\sim 1000 \mathrm{~Hz}$. In the further increase of sound frequency from $1000 \mathrm{~Hz}$ to $2000 \mathrm{~Hz}$ variation of sound absorption coefficient remains constant.

Sound absorption coefficient of fibres and fibre composites depends on many factors (Berardi, Iannace 2015; Xiang et al. 2013; Beghi 2013): material density, thickness, structure, pore size, fibre orientation and etc.

Berardi and Iannace (2015) have determined sound absorption coefficient of natural fibres at the frequency from $125 \mathrm{~Hz}$ to $2000 \mathrm{~Hz}$. In all intervals our determined values are higher. In our work values of sound absorption coefficient at frequencies of $500 \mathrm{~Hz}$, $1000 \mathrm{~Hz}$ and $2000 \mathrm{~Hz}$ were higher respectively of $76 \%$,

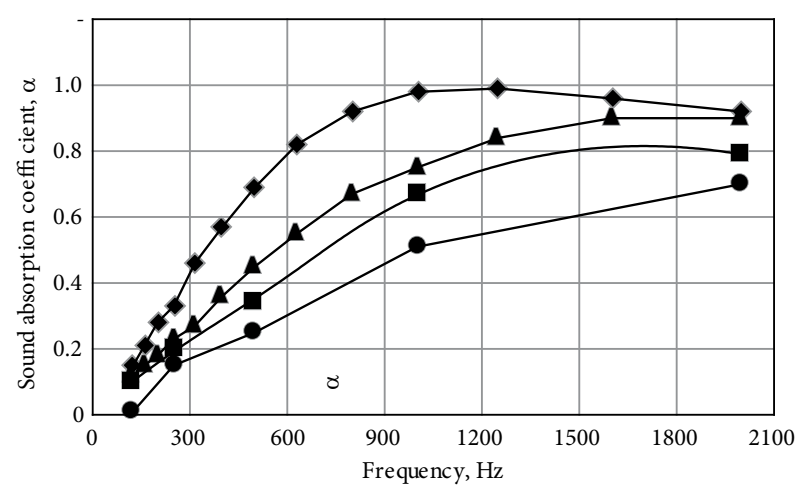

Fig. 4. Kinetic of sound absorption coefficient on sound frequency of hemp fibre composite: Our developed composite (densities, $\mathrm{kg} / \mathrm{m}^{3}: \mathbf{\Lambda}-40 ;-80$ ) and by other authors (Berardi, Iannace $(2015)\left(\bullet-50 \mathrm{~kg} / \mathrm{m}^{3}\right.$ hemp fibre, - $-60 \mathrm{~kg} / \mathrm{m}^{3}$ coconut fibre)
$47 \%$ and $29 \%$. Increasing frequency this difference decrease. Such results difference may be explained due to formation peculiarities - fibre orientation, pore size and etc.

Our results show that hemp fibre composites are characterised by good acoustical properties.

\subsection{Short-term water absorption}

Thermal insulation materials used in building envelopes may moisten. Due to moisture content changes physical-mechanical properties of materials. For this reason most building materials are resistant to moisture impact. In our experiments we used three different hydrophobic agents with different concentrations. Test results are presented in Figure 5. Natural fibres are very hydrophilic. Experimental studies show that using $0.25 \mathrm{~g} / \mathrm{l}$ of hydrophobic additives water absorption of hemp composite decrease two and more times. Hydrophobic effect also depends on additive type. The best hydrophobic additive for hemp composite at $0.25 \mathrm{~g} / 1$ concentration was Tubiguard 21. Water absorption level with this additive do not decrease increasing amount of additive from $0.25 \mathrm{~g} / 1$ to $1.75 \mathrm{~g} / \mathrm{l}$. Increasing concentration of additive Tubiguard 13 till $0.75 \mathrm{~g} / 1$ sudden decrease of water absorption is observed. In further experiments increasing concentration from $0.75 \mathrm{~g} / \mathrm{l}$ to $1.75 \mathrm{~g} / 1$ no effect was observed.

The third hydrophobic additive Beiphop FR significant effect shows just at concentration of $1.25 \mathrm{~g} / \mathrm{l}$. At concentration of $1.75 \mathrm{~g} / \mathrm{l}$ short-term water absorption values not changes. As it is seen in Fig. 5 all hydrophobic additives show good effect, but their concentrations differ. For further studies we have chosen Beiphob FR, because Tubiguard 21 and Tubiguard 13 (CHT-Bezema) are the fluorocarbon dispersions based

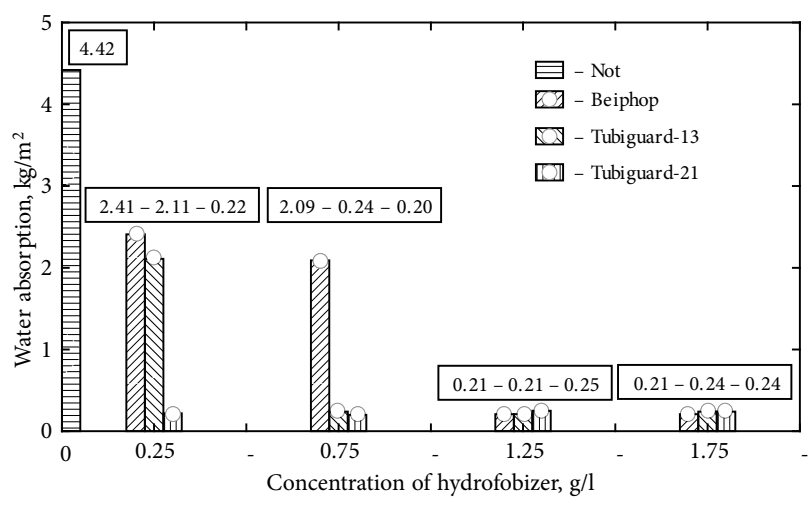

Fig. 5. Influence of hydrophobic additives on hemp fibre composite short-term water absorption 
on C8 chemistry with a low content of perfluorooctanoic acid (PFOA). It is more toxic compound than C6 chemistry derivative Beiphop FR.

Other scientists (Zach et al. 2013) have determined short-term water absorption of natural composites using hydrophobic additives based on silan named Lukofob 39, Drasil 153 and Tagal. Best results were obtained when hydrophobic additive Tagal was used. Water absorption results showed value of $0.36 \mathrm{~kg} / \mathrm{m}^{2}$. Comparing results we can state that our obtained water absorption values are about 1.4 time lower than by other authors (Zach et al. 2013). Such difference may be explained due to different materials coating method and chemical composition of hydrophobic additives.

\subsection{Water vapour permeability}

In our work hemp composite specimens with density of $40 \mathrm{~kg} / \mathrm{m}^{3}$ were used. For experiments hydrophobised and unhydrophobised specimens were prepared. As hydrophobic agent Beiphob FR with concentration $1.25 \mathrm{~g} / \mathrm{l}$ was used. Test results showed that water vapour transmittance of hemp fibres composite with hydrophobic agent is 1.80 , without hydrophobic agent 1.72. Comparing water vapour transmittance of hemp fibres composite with hydrophobic agent coating and uncoated specimens very small difference is observed. This difference may be due to materials heterogeneity. The hydrophobic additives do not create a single composite layer on the materials surface, so always free movement of water vapour is ensued. Researchers (Latif et al. 2014) have investigated the composite from hemp and polyester fibres and determined that water vapour transmittance of samples varied in the interval of 1.57 to 2.74 , when climatic conditions were 50/93. Comparing our results to the results obtained by the other scientists, values of water vapour transmittance are similar. Such water vapour transmittance provides a good temperature-moisture regime in building envelopes.

\subsection{Flammability}

All natural fibers are very flammable. To prevent their flammability, flame retardants are used. In our experiments two types of fire retardants were used - Flovan CGN and Apyrol BKW. In the initial stage it was necessary to determine the concentration of the flame retardant, which does not lead the burning of the product. Independently on the type of flame retardant results were very similar. In both cases the rational content of flame retardant was $45 \mathrm{~g} / \mathrm{l}$ (Fig. 6). Further increasing the amount of flame retardant, result not changes - no burning with fire and no fire overall, mass loss remains constant or changes insignificantly.

In Figure 7 test results of mass loss determination are presented. Low mass loss are observed with fire retardant concentrations $45 \mathrm{~g} / \mathrm{l}$ and $55 \mathrm{~g} / \mathrm{l}$. Using $45 \mathrm{~g} / \mathrm{l}$ Flovan CGN mass loss decrease $96.5 \%$ while using $45 \mathrm{~g} / \mathrm{l}$ Apyrol BKW - 96.1\%.

Spread of fire mode depends on the amount of flame retardant. When the specimen is fully coated with flame retardant, the fire effect is observed only in

a)

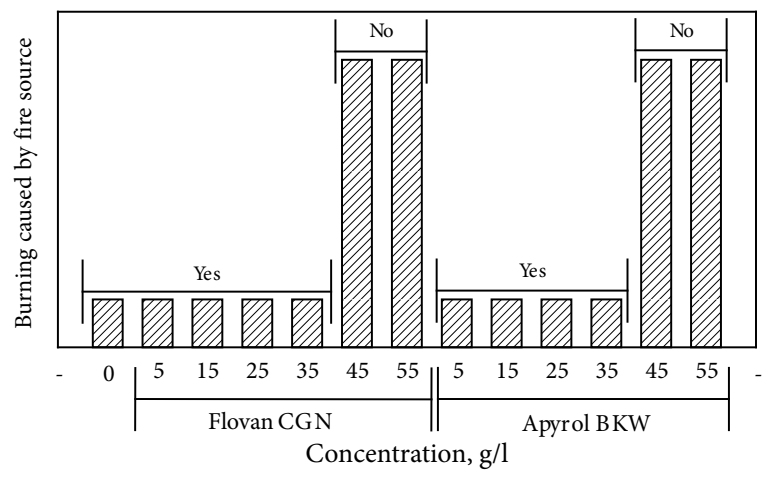

b)

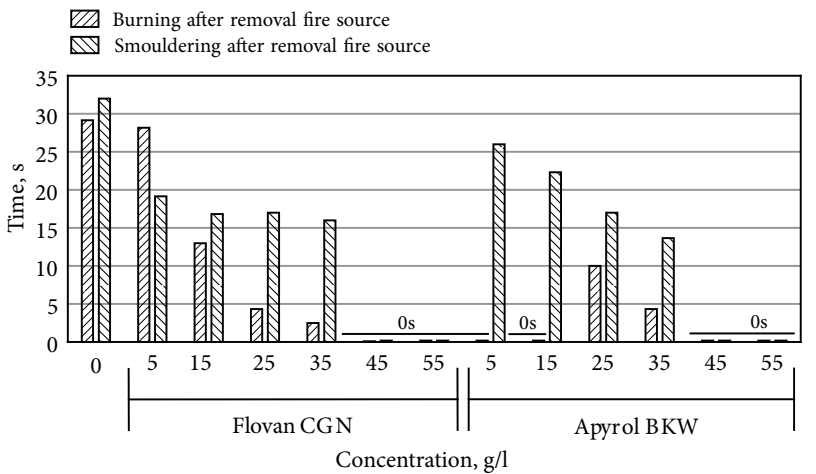

Fig. 6. Flamability of hemp fibre composite: a) burning caused by fire source; b) burning and smoldering time after removal fire source

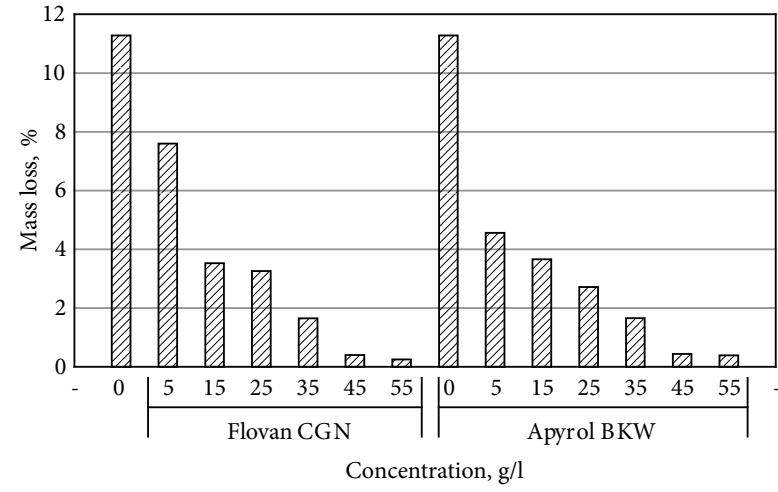

Fig. 7. Mass loss of hemp fiber composite during burning 

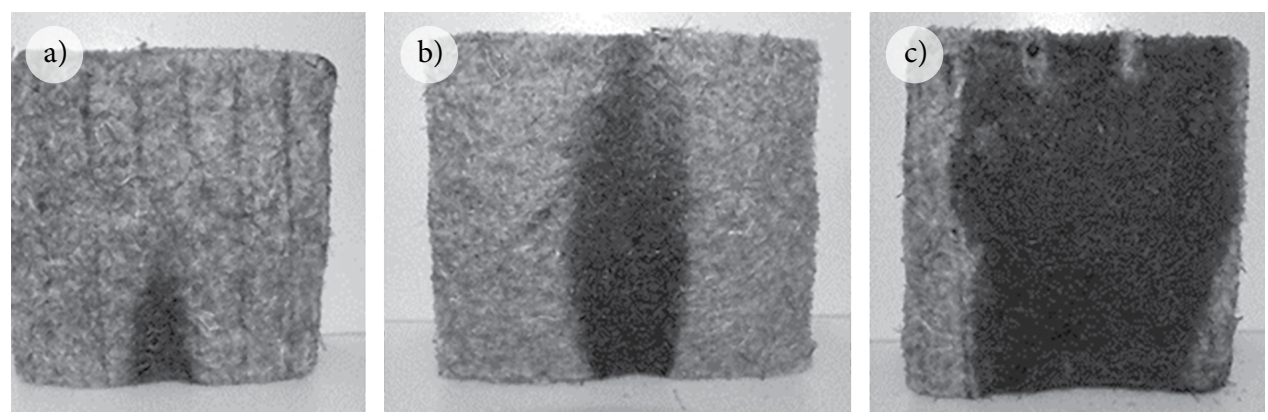

Fig. 8. View after flammability test of hemp fibre composite with different flame retardant concentrations, g/l: a) 55 ; b) 25 ; c) 5

the fire place point (Fig. 8a). When specimen fibres are not fully coated by flame retardant fire spread through the entire height of the sample is observed, but over the entire with the fire not spreads (Fig. 8b). When sample is coated or coated with small concentration of flame retardants the flame spread through the entire surface of the sample is observed (Fig. 8c).

The analysis of experimental data shows that mass loss of pure hemp fibres is more than $60 \%$ higher than mass loss of hemp fibre composite. For this reason we have tested pure polylactide fibres for flammability tests. Tests showed that polylactide fibres under the fire influence not burn, but melt and the mass loss is only $0.20 \%$. We can state that polylactide fibres in hemp fibre composite can reduce the spread of fire as well as mass loss. As polylactide fibres are entangled in throughout the composite, it prevents or slows burning of intersecting hemp fibres during fire exposure.

\section{Conclusions}

1. It was found that influence of amount of polylactide fibres on the thermal conductivity is negligible. Decrease of thermal conductivity of composite with amount of polylactide fibres $11 \%$ and $15 \%$ is about $4 \%$ at the range of densities from $40 \mathrm{~kg} / \mathrm{m}^{3}$ to $90 \mathrm{~kg} / \mathrm{m}^{3}$.

2. It was determined that increasing content of binding material from $11 \%$ to $15 \%$ compressive stress increase is about 2 times. On the other hand influence of density on the compressive strength is negligible - the difference is about $2 \%$ at the same content of binding material.

3. It was found that hemp fibres composite has good acoustical properties. Sound absorption coefficient of the composite with the density of $80 \mathrm{~kg} / \mathrm{m}^{3}$ at the frequency range from $800 \mathrm{~Hz}$ to $2000 \mathrm{~Hz}$ fluctuates about 0.9 and sound absorption coefficient of the composite with the density of $40 \%$ at the same frequency range varies from 0.7 to 0.9 .
4. It was found that small amount of hydrophobic additives reduces water absorption values of the composite several times. Water absorption values of unhydrophobised composite are higher than $4 \mathrm{~kg} /$ $\mathrm{m}^{2}$. In the case of hydrophobic additive $1.25 \mathrm{~g} / \mathrm{l}$, independently on the type of additive, water absorption values range only about $0.2 \mathrm{~kg} / \mathrm{m}^{2}$.

5. It was determined that hydrophobic additives do not effect on the water vapour transmittance or this influence is unimportant. Both hydrophobised and unhydrophobised composites have good water vapour permeability and the relative water vapour transmittance factor in both cases is not higher than 1.8 .

6. It was determined that polylactide fibres inhibit flammability of composite. Furthermore, use of flame retardants concentration of $45 \mathrm{~g} / 1$ protects hemp fibre composite against burning and smouldering.

\section{References}

Beghi, M. G. 2013. Modeling and measurement methods for acoustic waves and for acoustic microdevices. inTech.

Berardi, U.; Iannace, G. 2015. Acoustic characterization of natural fibers for sound absorption applications, Building and Environment 94(2): 840-852. http://dx.doi.org/10.1016/j.buildenv.2015.05.029

Chybik, J. 2009. Natural building materials. Prague: Grada Publishing. $272 \mathrm{p}$.

Corscadden, K. W.; Biggs, J. N.; Stiles, D. K. 2014. Sheep's wool insulation: A sustainable alternative use for a renewable resource?, Resources, Conversation and Recycling 86: 9-15. http://dx.doi.org/10.1016/j.resconrec.2014.01.004

Freivalde, L.; Kukle, S.; Andžs, M.; Bukšans, E.; Gravitis, J. 2014. Flammability of raw insulation materials made of hemp, Composites: Part B 67: 510-514.

Gnip, I.; Vejelis, S.; Keršulis, V.: Vaitkus, S. 2010. Strength and deformability of mineral wool slabs under short-term compressive, tensile and shear loads, Construction and Building Materials 24(11): 2124-2134.

Hepworth, D. G.; Bruce, D. M.; Vincent, J. F. V.; Jeronimidis, G. 2000. The manufacture and mechanical testing of thermosetting natural fibre composites, Journal of Materials Science 35: 293-298. http://dx.doi.org/10.1023/A:1004784931875 
Huber, T.; Müssig, J. 2008. Fibre matrix adhesion of natural fibres cotton, flax and hemp in polymeric matrices analysed with the single fibre fragmentation test, Composite Interfaces 15(23): 335-349. http://dx.doi.org/10.1163/156855408783810948

Jankauskiene, Z.; Gruzdevienè, E. 2015. Screening of industrial hemp (Cannabis sativa L.) cultivars for biomass yielding capacities in Lithuania, Journal of Natural Fibers 12: 368-377. http://dx.doi.org/10.1080/15440478.2014.929556

Korjenic, A.; Zach, J.; Hroudova, J. 2016. The use of insulating materials based on natural fibers in combination with plant facades in building constructions, Energy and Building 116: $45-58$.

Latif, E.; Tucker, S.; Ciupala, M. A.; Wijeyesekera, D. C.; Newport, D. 2014. Hygric properties of hemp bio-insulations with differing compositions, Construction and Building Materials 66: 702-711.

Lukošiūtè. I. 2014. Pluoštiniu kanapių auginimo ekonominiu galimybiu analizé: Ataskaita. Lietuvos agrarinès ekonomikos institutas Produktų rinkotyros skyrius (in Lithuanian).

LST EN 12667:2002. Šiluminès statybinių medžiagų ir gaminių savybès. Šiluminès varžos nustatymas apsaugotos karštosios plokštès ir šilumos srauto matuoklio metodais. Didelès ir vidutinès šiluminès varžos gaminiai [Thermal performance of building materials and products - Determination of thermal resistance by means of guarded hot plate and heat flow meter methods - Products of high and medium thermal resistance]. Lithuanian standart.

LST EN 12939:2002. Šiluminès statybinių medžiagų ir gaminių savybès. Šiluminès varžos nustatymas apsaugotos karštosios plokštès ir šilumos srauto matuoklio metodais. Stori didelès ir vidutinès šiluminès varžos gaminiai [Thermal performance of building materials and products - Determination of thermal resistance by means of guarded hot plate and heat flow meter methods - Thick products of high and medium thermal resistance]. Lithuanian standart.

LST EN 1608:2013. Statybiniai termoizoliaciniai gaminiai. Lygiagretaus paviršiams tempimo stiprio nustatymas [Thermal insulating products for building applications - Determination of tensile strength parallel to faces]. Lithuanian standart.

LST EN 1609:2013. Statybiniai termoizoliaciniai gaminiai. Trumpalaikès vandens sugerties iš dalies panardinus jame nustatymas [Thermal insulating products for building applications - Determination of short term water absorption by partial immersion]. Lithuanian standart.

LST EN 12086:2013. Statybiniai termoizoliaciniai gaminiai. Pralaidumo vandens garui nustatymas [Thermal insulating products for building applications - Determination of water vapour transmission properties]. Lithuanian standart.
LST EN ISO 11925-2:2010/AC:2011. Reakcijos ị ugnị bandymai. Gaminių užsidegamumas tiesiogiai veikiant liepsna. 2 dalis. Bandymas pavieniu liepsnos šaltiniu [Reaction to fire tests - Ignitability of products subjected to direct impingement of flame - Part 2: Single-flame source test]. Lithuanian standart.

LST EN ISO 10534-1:2002. Akustika. Garso sugerties koeficiento ir pilnutines varžos nustatymas interferometrais. 1 dalis. Stovinčios bangos santykio metodas (ISO 10534-1:1996) [Acoustics - Determination of sound absorption coefficient and impedance in impedances tubes - Part 1: Method using standing wave ratio (ISO 10534-1:1996)]. Lithuanian standart.

LST EN ISO 8301:1991. Thermal insulation -- Determination of steady-state thermal resistance and related properties -- Heat flow meter apparatus, Subcommittee SC 1, Test and measurement methods.

Mansour, E.; Loxton, C.; Elias, R. M.; Ormondroyd, G. A. 2014. Assesment of health implications related to processing and use of natural wool insulation products, Environment International 73: 402-412.

Müssig, J. 2010. Industrial applications of natural fibres, structure, properties and technical applications. John Wiley and Sons, Ltd.

Palumbo, M; Avellaneda, J.; Lacasta, A. M. 2015. Availability of crop by-products in Spain: New raw materials for natural thermal insulation, Resources, Conversation and Recycling 99: 1-6. http://dx.doi.org/10.1016/j.resconrec.2015.03.012

Papadopoulos, A. M. 2005. State of the art in thermal insulation materials and aims for future developments, Energy and Buildings 37: 77-86.

Sain, M.; Park, S. H.; Suhara, F.; Law, S. 2004. Flame retardant and mechanical properties of natural fibre-PP composites containing magnesium hydroxide, Polymer Degradation and Stability 83: 363-367.

Spiridon, I. 2014. I. Natural fiber-polyolefin composites. Mini-review, Cellulose Chemistry and Technology 48(7-8): 599-612.

Xiang, H.-F.; Wang, D.; Lui, H.-C.; Zhao, N.; Xu, J. 2013. Investigation on sound absorption properties of kapok fibers, Chinese Journal of Polymer Science 31(3): 521-529. http://dx.doi.org/10.1007/s10118-013-1241-8

Thomsen, A. B.; Rasmussen, S.; Bohn, V.; Nielsen, K. V.; Thygesen, A. 2005. Hemp raw materials: The effect of cultivar, growth conditions and pretreatment on the chemical composition of the fibres. Biosystems Departament.

Zach, J.; Hroudova, J.; Brožovsky, J.; Zdenek, K.; Gailius, A 2013. Development of thermal insulating materials on natural base for thermal insulation systems, Procedia Engineering 57: $1288-1294$.

http://dx.doi.org/10.1016/j.proeng.2013.04.162

Rūta STAPULIONIENĖ (Corresponding author), PhD student, senior engineer of Vilnius Gediminas Technical University Scientific Institute of Thermal Insulation (VGTU). Research interests: development and research of thermal insulation from local renewable resources, natural fibres.

Saulius VAITKUS, Dr. Senior research scientist of Vilnius Gediminas Technical University Scientific Institute of Thermal Insulation (VGTU). Research interests: investigations of physical-mechanical and thermal-technical characteristics of thermal insulating materials and products; development and research of thermal insulation from local renewable resources, natural fibres.

Sigitas VE்JELIS, Dr. Chief research scientist of Vilnius Gediminas Technical University Scientific Institute of Thermal Insulation (VGTU). Research interests: investigations of physical-mechanical and thermal-technical characteristics of thermal insulating materials and products; development and research of thermal insulation from local renewable resources, natural fibres. 